\title{
Molecular cloning of a laccase isozyme gene from Pleurotus sajor-caju and expression in the heterologous Pichia pastoris host
}

\author{
D. M. Soden, ${ }^{1}$ J. O'Callaghan ${ }^{2}$ and A. D. W. Dobson ${ }^{2}$
}

National Food

Biotechnology Centre ${ }^{1}$ and Microbiology Department ${ }^{2}$ University College, National University of Ireland, Cork, Ireland
Author for correspondence: A. D. W. Dobson. Tel: +353 21 4902743. Fax: +353214903101. e-mail: a.dobson@ucc.ie

The Psc lac4 gene from Pleurotus sajor-caju has been cloned and expressed in the heterologous host Pichia pastoris, under the control of the AOX1 methanol inducible promoter. The native Ple. sajor-caju laccase signal sequence was effective in directing the secretion of lac4 expressed in Pic. pastoris. The control of media pH and temperature was found to be important in obtaining sufficient quantities of the protein to allow purification and subsequent biochemical characterization. The recombinant Psc Lac4 was purified to electrophoretic homogeneity and was shown to be immunologically related to Pleurotus eryngii Lac1. The purified laccase was estimated to have a molecular mass of around $59 \mathrm{kDa}$, to have a carbohydrate content of approximately $7 \%$ and a calculated pl of 4-38. The enzyme oxidized the substrates 2,2-azinobis(3-ethylbenzthiazoline-6-sulphonate) (ABTS), 2,6-dimethoxyphenol, syringaldazine and guaiacol, exhibiting optimal pHs of $3 \cdot 3,6,6.5$ and 7 respectively. With ABTS as substrate the enzyme displayed optimal activity at $35{ }^{\circ} \mathrm{C}$ and pH 3.5. The enzyme was strongly inhibited by sodium azide and thioglycolic acid but not by EDTA.

Keywords: white-rot fungus, heterologous expression, laccase, biochemical characterization

\section{INTRODUCTION}

The white-rot fungus Pleurotus sajor-caju is a member of the oyster mushroom family. This edible basidiomycete secretes a range of enzymes, most notably laccases and peroxidases, which enable it to grow on a variety of different substrates (Toyama \& Ogawa, 1974). Laccase is a copper-containing phenoloxidase catalysing the four-electron reduction of $\mathrm{O}_{2}$ to $\mathrm{H}_{2} \mathrm{O}$ with the concomitant oxidation typically of a phenolic substrate. This one-electron oxidation generates a free radical, which is typically unstable and may undergo a second enzyme-catalysed oxidation or a non-enzymic reaction such as hydration or spontaneous disproportionation and/or may partake in a polymerization reaction (Thurston, 1994).

Laccases are members of the blue copper oxidase enzyme family that typically contain four copper atoms per

Abbreviations: ABTS, 2,2-azinobis(3-ethylbenzthiazoline-6-sulphonate); DMP, 2,6-dimethoxyphenol; GRAS, generally regarded as safe.

The GenBank accession number for the sequence of the Pleurotus sajorcaju laccase 4 gene (lac4) reported in this paper is AF297228. molecule. The distinctive spectroscopic and physical properties of the various copper centres within the protein allow for classification into three different kinds of copper sites: type 1 (T1), type 2 (T2) and type 3 (T3) (Malkin \& Malmstrom, 1970). T1 copper is responsible for the intense blue colour, absorbs maximally in the visible range and is responsible for both abstracting electrons from the substrate and delivering them to the T2 and T3 sites. The type 2 copper exhibits lower visible absorbance and the type 3 site incorporates two copper centres and is responsible for a shoulder near $330 \mathrm{~nm}$ in the absorbance spectrum of native laccase. All these copper ions appear to be involved in the catalytic mechanism. Amino acid sequence analysis of different laccases indicates that the copper-binding sites, involving ten-histidine residues, are very highly conserved.

Various fungi, several insects (Thomas et al., 1989), bacteria (Alexandre \& Zhulin, 2000; Sanchez-Amat et al., 2001; Martins et al., 2002) and recently wasp venom (Parkinson et al., 2001) have been shown to produce/ contain laccase. The biological role for laccase has as yet not been fully elucidated and appears to vary depending on the type of organism (Thurston, 1994). In fungi 
laccase has been shown to act as a ligninolytic enzyme (Eggert et al., 1997), to be involved in fruiting body formation (Wood, 1980), in pigmentation (Leatham \& Stahmann, 1981) and in pathogenicity (Choi et al., 1992).

Laccases are remarkably substrate non-specific and can directly oxidize a broad range of diverse phenolic compounds including chlorophenols (Field et al., 1993), methoxyphenols (Eriksson et al., 1990), hydroquinones (Baker et al., 1996) as well as di- and triamines (Harkin et al., 1974). The ability of laccases to oxidize catechol, guaiacol, 2,6-dimethoxyphenol (DMP) and syringaldazine is considered diagnostic (Leatham \& Stahmann, 1981). Syringaldazine has also been reported to act as a mediator (co-oxidant) facilitating the oxidation of nonphenolic subunits in lignin (Kawai et al., 1989). Other mediators such as 2,2-azinobis(3-ethylbenzthiazoline-6sulphonate) (ABTS) (Bourbonnais et al., 1995) and 1hydroxy-benzotriazole (Bourbonnais et al., 1997) have also been reported. In the presence of these mediators laccase can catalyse the oxidation of polycyclic aromatic hydrocarbons (Collins et al., 1996) and benzyl alcohols (Potthast et al., 1996), and can bleach textile dyes (Schneider \& Pedersen, 1995). These characteristics of laccase have led to applications in selected bioremediation strategies (Gianfreda et al., 1999), as a catalyst for regiospecific biotransformations (Agematu et al., 1993), as a biosensor in immunoassays (Ghindilis et al., 1995), in the treatment of wastewater (Shuttleworth \& Bollag, 1986; Larsson et al., 2001) and in the removal of natural phenols from oil (Tomati et al., 1991).

In an attempt to understand the functional role of fungal laccases, a number of laccase genes have been cloned and characterized including those from Aspergillus nidulans (Aramayo \& Timberlake, 1990), Pycnoporus cinnabarinus (Eggert et al., 1997), Rhizoctonia solani (Wahleithner et al., 1996), Trametes versicolor (Jönsson et al., 1995), Trametes villosa (Yaver et al., 1996) and Trametes I-62 (CECT 20197) (Mansur et al., 1997). However, despite this, the biochemical characterization of these laccases has been difficult due to the low levels of expression in their native systems. A solution to this problem is the production of sufficient quantities of the recombinant protein in a heterologous host. In this regard the methylotrophic yeast Pichia pastoris has proven useful, with this yeast having previously been used to express laccases from T. versicolor (Jönsson et al., 1997; Gelo-Pujic et al., 1999; Brown et al., 2002), Trametes sanguinea (Hoshida et al., 2001) and Pyc. cinnabarinus (Otterbein et al., 2000). In addition, Saccharomyces cerevisiae (Kojima et al., 1990; Cassland \& Jönsson, 1999), Trichoderma reesei (Saloheimo \& Niku-Paavola, 1991), Aspergillus oryzae (Yaver et al., 1996) and Aspergillus niger (Record et al., 2002) have also been used for the heterologous expression of fungal laccases. Recently the bacterial laccase gene $\cot A$ from Bacillus subtilis has been expressed in Escherichia coli (Martins et al., 2002).

We have previously described the cloning of four laccase isozyme genes from Ple. sajor-caju (Soden \& Dobson, 2001). Here we report on the expression of one of these isozyme genes, namely Psc lac4 in the heterologous Pic. pastoris system and demonstrate the use of this system to produce sufficient quantities of recombinant pLac 4 protein to allow its biochemical characterization.

\section{METHODS}

Organisms and vectors for cloning and expression. The basidiomycete Pleurotus sajor-caju strain P32-1 was maintained as previously described (Soden \& Dobson, 2001). Pichia pastoris and the strains GS115 (his4) and KM71 (arg4 his4) were purchased from Invitrogen. Cloning procedures were performed using a laboratory stock of E. coli DH5 $\alpha$ and One Shot INV $\alpha \mathrm{F}^{\prime}$ Chemically Competent E. coli (Invitrogen). PCR products were cloned into the pCR2.1-Topo vector (Invitrogen). The vectors pPIC3.5 and pPIC9 (Invitrogen) were used for expression in Pic. pastoris. Expression of inserts in both vectors is controlled by the methanol-inducible AOX promoter. pPIC9 possesses the $\alpha$-secretion factor from Sac. cerevisiae while pPIC3.5 does not contain a secretion signal. All media and protocols for Pichia are as described in the Pichia expression manual (Invitrogen).

DNA sequencing and analysis. Sequence was determined by the dideoxy chain termination method (Sanger et al., 1977) using the Dye Terminator Cycle Sequencing Ready Reaction with AmpliTaq DNA polymerase (Applied Biosystems) on a GeneAmp PCR system 2400 (Perkin Elmer) and run on an automated DNA sequencer (model 373 stretch, Applied Biosystems). The sequence data were assembled and processed using the DNASTAR software package. The BLAST algorithm (Altschul et al., 1990) was used to search DNA and protein databases for similarity. The CLUSTAL program (Higgins \& Sharp, 1989) was used for alignment of amino acid sequences.

RNA-PCR. Total RNA was prepared by a modification of the method of Gromroff et al., 1989 and as described previously (Soden \& Dobson, 2001). Reverse transcription was carried out using Superscript II RNase H (Gibco-BRL and Invitrogen) using the following protocol. Total RNA $(1.5 \mu \mathrm{g})$ and $80 \mathrm{pmol}$ of the oligo $\mathrm{dT}$ primer (Table 1 ) in a reaction volume adjusted to $10 \cdot 5 \mu \mathrm{l}$ with HPLC grade $\mathrm{dH}_{2} \mathrm{O}$ were heated to $72^{\circ} \mathrm{C}$ for 2 min. This was added to $1 \times \mathrm{RT}$ buffer, $1 \mathrm{mM}$ DTT, $1 \mathrm{mM}$ each deoxynucleoside triphosphates (dNTPs), $20 \mathrm{U}$ RNasin inhibitor and $1 \mu \mathrm{l}$ Superscript II RNase $\mathrm{H}$ reverse transcriptase, in a total volume of $20 \mu \mathrm{l}$. The reaction was heated to $42^{\circ} \mathrm{C}$ for $150 \mathrm{~min}$ and placed on ice. PCR amplification was carried out with the AmpliTaq Gold proof reading DNA polymerase (Perkin Elmer, Roche Molecular Systems). Amplification of the lac4 cDNA from Ple. sajor-caju was performed using the primers, pLac4 ATG Fw and pLac4 Rev (Table 1). A $5 \mu l$ volume from the RT reaction mixture was mixed with 10 pmol of each primer, $1 \times$ AmpliTaq PCR gold buffer, $1.5 \mathrm{mM} \mathrm{MgCl}, 200 \mu \mathrm{M}$ (each) dNTPs and $1.25 \mathrm{U}$ of AmpliTaq gold DNA polymerase. Reaction volumes were adjusted to $100 \mu \mathrm{l}$ with HPLC-grade water. Amplification was performed in a PTC-100 programmable thermal controller (MJ Research) with 1 cycle of $94^{\circ} \mathrm{C}$ for $3 \mathrm{~min}$ followed by 10 cycles of denaturation $\left(30 \mathrm{~s}\right.$ at $\left.94^{\circ} \mathrm{C}\right)$, annealing $(30 \mathrm{~s}$ at $55^{\circ} \mathrm{C}$ ) and extension $\left(100 \mathrm{~s}\right.$ at $\left.72{ }^{\circ} \mathrm{C}\right), 10$ cycles of $30 \mathrm{~s}$ at $94{ }^{\circ} \mathrm{C}, 30 \mathrm{~s}$ at $55^{\circ} \mathrm{C}$ and $150 \mathrm{~s}$ at $72^{\circ} \mathrm{C}, 10$ cycles of $30 \mathrm{~s}$ at $94^{\circ} \mathrm{C}, 30 \mathrm{~s}$ at $55^{\circ} \mathrm{C}$ and $4 \mathrm{~min}$ at $72{ }^{\circ} \mathrm{C}$, and a final step of $72{ }^{\circ} \mathrm{C}$ for $10 \mathrm{~min}$. PCR products were loaded on a $1.5 \%$ agarose gel and electrophoresed in TAE buffer (40 mM Tris/ acetate, $1 \mathrm{mM}$ EDTA) for $2 \mathrm{~h}$ at $90 \mathrm{~V}$. The gel was stained with ethidium bromide, visualized under UV light and a single PCR 
White-rot fungal laccase

Table 1. Gene-specific primer sequences and annealing temperatures

\begin{tabular}{|llc|}
\hline Name & \multicolumn{1}{c|}{ Primer sequence } & $\begin{array}{r}\text { Annealing temp. } \\
\left({ }^{\circ} \mathrm{C}\right)\end{array}$ \\
\hline oligo dT primer & TTTTTTTTTTTTTTT & 42 \\
pLac4 ATG Fw & CTGCTACACCTACCAACGATGGTTC & 55 \\
pLac4 Rev & GCAAATGGCATTCTGAC & 55 \\
pLac4-SS Fw & CGAATTCTGCCATTCGGCCCGCTGGCA & 55 \\
pLac4-SS Rev & GCAAATGGCATTCTGACATCC & 55 \\
$5^{\prime}$ Aox Fw & GACTGGTTCCAATTGACAAGC & 55 \\
$3^{\prime}$ Aox Rev & GCAAATGGCATTCTGACATCC & 55 \\
\hline
\end{tabular}

product of $\sim 1.7 \mathrm{~kb}$ was cut and purified using the QiaQuick purification kit (Qiagen).

Gene cloning/construction of vectors. The purified laccase cDNA was cloned into the pCR2.1-Topo vector, subsequently excised using EcoRI, followed by purification from an agarose gel and insertion into pPIC3.5, resulting in the vector pPIC3.5lac4. For cloning into pPIC9, PCR amplification of the lac4 cDNA in the pCR2.1-Topo vector was performed with the primers, pLac4-SS Fw and pLac4-SS Rev (Table 1). The primer pPIC9-SS Fw does not contain a Kozak consensus sequence like pPIC3.5-lac4 Fw, as it is present in the $\alpha$ secretion signal for pPIC9. The PCR conditions employed were as previously described for lac $4 \mathrm{cDNA}$. The resultant PCR product, lac4-SS was cloned into pPIC9 in the same manner as for pPIC3.5, resulting in the vector pPIC9-lac4-SS. After transformation of E. coli and isolation of plasmid DNA, the presence and orientation of the inserts was determined both by PCR and by restriction enzyme digestion followed by agarose-gel electrophoresis. The primers 5' Aox Fw and 3' Aox Rev (Table 1) were used to determine the presence of inserts in pPIC3 and pPIC9 using a PCR protocol as described in the Pichia expression manual. Sequence analysis was ultimately performed on pPIC3.5-lac4 and pPIC9-lac4-SS, to ensure the integrity of the constructs. All restriction enzymes used for cloning and restriction analysis were purchased from Roche. Techniques for cloning were as described by Ausubel et al. (1996). All chemicals were of analytical grade unless otherwise stated.

Transformation and detection of expression in Pic. pastoris. Pic. pastoris was transformed by the electroporation method. pPIC3.5-lac4 and pPIC9-lac4-SS plasmid DNA was digested with StuI prior to transformation into electrocompetent cells of Pic. pastoris. The vectors pPIC3.5 and pPIC9 without inserts were simultaneously transformed into Pic. pastoris and used as controls. Transformant colonies were picked from minimal glucose (MD) plates and transferred to plates with either MD or minimal methanol (MM) as the carbon source, for examination of methanol utilization. Colonies were spotted onto MM plates supplemented with $0.2 \mathrm{mM}$ ABTS and $0 \cdot 1 \mathrm{mM} \mathrm{CuSO}$. Laccase-producing transformants were identified by the presence of a dark green colour around the Pichia colonies.

Production of laccase in liquid media. Colonies producing a green zone/halo were further analysed in liquid cultures. Laccase activity in these cultures was determined spectrophotometrically using $600 \mu \mathrm{l}$ cell-free supernatant, $250 \mu \mathrm{l}$ $\mathrm{dH}_{2} \mathrm{O}, 100 \mu \mathrm{l} 1 \mathrm{M}$ NaOAc buffer, $\mathrm{pH} 6$; with the reaction being initiated by the addition of $50 \mu \mathrm{l} 10 \mathrm{mM}$ ABTS. The reaction was monitored at $420 \mathrm{~nm}$ and $25^{\circ} \mathrm{C}$ with a Beckman $\mathrm{Du}^{\circledR} 640$ spectrophotrometer. Ten transformants of both
pPIC3-lac4 and pPIC9-lac4-SS in both Pic. pastoris GS115 and KM71 along with the controls for pPIC3.5 and pPIC9 were cultivated first at $28{ }^{\circ} \mathrm{C}$ in $15 \mathrm{ml}$ volumes $(50 \mathrm{ml}$ baffled shake flasks) of buffered glycerol minimal medium (BGM) until the optical density at $600 \mathrm{~nm}\left(\mathrm{OD}_{600}\right)$ was approximately 10 . The culture was centrifuged $\left(1200 \mathrm{~g}\right.$ at $4{ }^{\circ} \mathrm{C}$ for $10 \mathrm{~min}$.) and washed with $0.9 \%(\mathrm{w} / \mathrm{v}) \mathrm{NaCl}$. The sample was recentrifuged and the cell pellet was diluted with buffered methanol minimal (BMM) medium to an OD of $\sim 1$ in $100 \mathrm{ml}$ baffled shake flasks. Transformants were cultivated at $20^{\circ} \mathrm{C}$ in $\mathrm{BMM}$ medium, shaking at 160 r.p.m. (supplemented with $0 \cdot 1 \mathrm{mM}$ $\mathrm{CuSO}_{4}, 0.8 \%$ alanine $)$ and methanol $(0.5 \%$ of the total volume of medium) was added daily to maintain the induced production of laccase. Samples were analysed daily for laccase activity using the ABTS assay and cell growth was also measured by taking $\mathrm{OD}_{600}$ readings $\left(1 \mathrm{OD}_{600}=\sim 5 \cdot 0 \times 10^{7}\right.$ cells). Experiments involving comparison of strains were performed with triplicate transformants to allow for variations in yield.

During preliminary studies on laccase production by the transformants it was noted that the $\mathrm{pH}$ of the cultures decreased rapidly from $\mathrm{pH} 6$ to $\mathrm{pH} 3$. The $\mathrm{BMM}$ media was supplemented with $0 \cdot 8 \%$ alanine, allowing the $\mathrm{pH}$ to remain at 6.

Enzyme purification. The liquid culture $(1 \cdot 8 \mathrm{l})$ was centrifuged at $10000 \mathrm{~g}$ for $30 \mathrm{~min}$ and the subsequent cell-free supernatant was further filtered through a $0.45 \mu \mathrm{m}$ filter (Millipore) to remove any remaining cell debris. The sample was then concentrated on an Amicon ultrafiltration stirred cell using a PM-10 membrane and buffered with $100 \mathrm{mM}$ sodium acetate, $\mathrm{pH}$ 5. The subsequent purification steps were carried out at $4{ }^{\circ} \mathrm{C}$. Partial purification of the laccase was initially performed using a Sephadex G-75 chromatography column $(2.6 \times 10 \mathrm{~cm}$, Amersham) with $100 \mathrm{mM}$ sodium acetate buffer, $\mathrm{pH} \mathrm{5}$, at

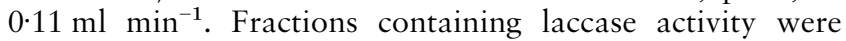
pooled and reconcentrated using the Amicon PM-10 membrane. The concentrate was dialysed against $20 \mathrm{mM}$ Tris buffer, pH 8.5, and loaded onto a Q-Sepharose $(2.75 \times 11 \mathrm{~cm})$ (Pharmacia Biotech AB) anion exchange column (Bio-Rad). The dialysis tubing had a molecular mass cutoff of $3 \mathrm{kDa}$. Ten column volumes of the same buffer were passed through the column before elution with a step-wise increase in the $\mathrm{NaCl}$ gradient $(0$ to $0.6 \mathrm{M})$ in the same buffer. The fractions containing laccase activity were pooled and concentrated. The concentrate was dialysed against $20 \mathrm{mM}$ Tris, $\mathrm{pH}$. The purified laccase was stored at $4^{\circ} \mathrm{C}$. The degree of enzyme purity was confirmed by SDS-PAGE.

Electrophoresis. Polyacrylamide $(12 \%)$ gel slab electrophoresis in $0 \cdot 1 \%$ SDS was carried out as described by Laemmli (1970). For molecular mass determinations, the gel was 
calibrated with $\alpha_{2}$-macroglobulin $(180 \mathrm{kDa}), \beta$-galactosidase $(116 \mathrm{kDa})$, fructose-6-phosphate kinase $(84 \mathrm{kDa})$, pyruvate kinase $(58 \mathrm{kDa})$, fumarase $(48 \cdot 5 \mathrm{kDa})$, lactic dehydrogenase $(36.5 \mathrm{kDa})$ and triosephosphate isomerase $(26.6 \mathrm{kDa})$. Proteins were visualized after staining with Coomassie brilliant blue R-250 $(0 \cdot 1 \%)$.

Protein determination. Protein concentration was determined using the Bio-Rad Protein Assay, based on the Bradford (1976) dye-binding procedure, with bovine serum albumin (BSA) as standard.

Immunoblot analysis. SDS-PAGE was performed on a $12 \%$ $(\mathrm{w} / \mathrm{v})$ polyacrylamide gel. Electrotransfer of proteins was carried out according to the method of Towbin et al. (1979). The proteins were electrotransferred to a nitrocellulose membrane for $1 \mathrm{~h}$ at $170 \mathrm{~mA}$ in a Bio-Rad transblot apparatus. The membrane was blocked by incubation with $0.5 \%$ BSA in TBST [10 mM Tris (pH 8.0), $150 \mathrm{mM} \mathrm{NaCl,} 0 \cdot 05 \%$ Tween 20] for $30 \mathrm{~min}$ at room temperature. The membrane was incubated in TBST containing anti-laccase (Pleurotus eryngii) antiserum at a 1:100 dilution overnight and then washed with TBST for $30 \mathrm{~min}$. It was incubated again in TBST containing anti-mouse IgG (whole molecule) alkaline phosphatase conjugate at 1:10000 dilution for $90 \mathrm{~min}$, washed with TBST for $30 \mathrm{~min}$ and developed with nitro blue tetrazolium plus 5-bromo-4-chloro-3-indolyl phosphate in alkaline phosphatase buffer [100 mM Tris (pH 9.5), $100 \mathrm{mM}$ $\mathrm{NaCl}, 5 \mathrm{mM} \mathrm{MgCl}_{2}$ ]. The laccase-specific antibodies used for immunological detection were generated against purified laccase from Ple. eryngii (Muñoz et al., 1997).

Endoglycosidase treatment. N-linked glycans of Psc Lac4 were removed with $\mathrm{N}$-glycosidase $\mathrm{F}$ (Roche Diagnostics). Purified Psc Lac4 ( 5 $\mu \mathrm{g})$ was denatured by heating at $100{ }^{\circ} \mathrm{C}$ for $3 \mathrm{~min}$ in $1.2 \%(\mathrm{w} / \mathrm{v})$ SDS, then diluted in buffer to $25 \mu \mathrm{l}$ (final composition $10 \mathrm{mM}$ sodium phosphate buffer, $\mathrm{pH} 6 \cdot 8$; $5 \mathrm{mM}$ EDTA; $0 \cdot 1 \mathrm{M} \beta$-mercaptoethanol; $0 \cdot 3 \%$ Nonidet P-40; $0.4 \%$ SDS). After adding $1 \mathrm{U}(1 \mu \mathrm{l}) \mathrm{N}$-glycosidase $\mathrm{F}$, the sample was incubated at $37^{\circ} \mathrm{C}$ overnight and then analysed by SDS-PAGE. A control in which the glycosidase was substituted with deionized $\mathrm{H}_{2} \mathrm{O}$ was prepared in an identical fashion. The carbohydrate content of the laccase was estimated by comparison of the migration of native and treated enzyme on SDSPAGE gel.

Enzyme assays. Laccase activity was assayed at $25^{\circ} \mathrm{C}$ using (a) ABTS, (b) DMP, (c) syringaldazine and (d) guaiacol as substrates as follows. (a) The assay mixture contained $0.5 \mathrm{mM}$ ABTS and $0 \cdot 1 \mathrm{M}$ sodium acetate buffer, $\mathrm{pH} 3 \cdot 3$. Oxidation of ABTS was followed by absorbance increase at $420 \mathrm{~nm}$ $\left(\varepsilon=36000 \mathrm{M}^{-1} \mathrm{~cm}^{-1}\right)$. (b) The assay mixture contained $1 \mathrm{mM}$ DMP and $0 \cdot 1 \mathrm{M}$ sodium phosphate buffer, $\mathrm{pH} 6 \cdot 0$. Oxidation of DMP was followed by absorbance increase at $477 \mathrm{~nm}$ $\left(\varepsilon=14800 \mathrm{M}^{-1} \mathrm{~cm}^{-1}\right)$. (c) The assay mixture contained $0.5 \mathrm{mM}$ syringaldazine (dissolved in ethanol) and $0.1 \mathrm{M}$ sodium phosphate buffer, $\mathrm{pH} 6 \cdot 5$. Oxidation of syringaldazine was followed by an absorbance increase at $525 \mathrm{~nm}(\varepsilon=65000$ $\mathrm{M}^{-1} \mathrm{~cm}^{-1}$ ). (d) The assay mixture contained $10 \mathrm{mM}$ guaiacol (dissolved in $10 \%$ acetone) and $0 \cdot 1 \mathrm{M}$ sodium phosphate buffer, pH 6.5. Oxidation was followed by absorbance increase at $460 \mathrm{~nm}$. Tyrosinase activity was assayed at $25^{\circ} \mathrm{C}$ using 3,4-dihydroxy-DL-phenylalanine (DL-dopa) as substrate. The assay mixture contained $0 \cdot 2 \mathrm{mM}$ DL-dopa and $0 \cdot 1 \mathrm{M}$ sodium phosphate, $\mathrm{pH} 6$. The oxidation of substrate was followed by an absorbance increase at $475 \mathrm{~nm}$ $\left(\varepsilon=3600 \mathrm{M}^{-1} \mathrm{~cm}^{-1}\right)$ (Palmieri et al., 1997). All kinetic studies were performed at least three times and the kinetic data were fitted to hyperbola by using the Michaelis-Menton equation. All enzyme activity is expressed as international units (IU).
pH activity and stability. Laccase activity as a function of $\mathrm{pH}$ for ABTS, guaiacol, syringaldazine and DMP was measured using McIlvaine's citrate-phosphate buffer adjusted to different $\mathrm{pH}$ levels in the range $2 \cdot 2-8 \cdot 0$ at $25^{\circ} \mathrm{C}$. To determine the $\mathrm{pH}$ stability, the purified laccase was incubated at either $4{ }^{\circ} \mathrm{C}$ or $25^{\circ} \mathrm{C}$ and the activity measured at selected times up to $300 \mathrm{~min}$, using ABTS as substrate. The same buffer was used to determine the $\mathrm{pH}$ stability.

Temperature activity and stability. Laccase activity as a function of temperature was measured after pre-incubation of $50 \mu \mathrm{g}$ purified protein for $5 \mathrm{~min}$ at 10, 20, 30, 35, 40, 45, 50, 60, 70 and $80^{\circ} \mathrm{C}$ in $100 \mathrm{mM}$ sodium acetate buffer, $\mathrm{pH}$ 5. ABTS was used as substrate for determining activity. Thermal stability was estimated by incubating the purified laccase at $35,45,55$ and $65^{\circ} \mathrm{C}$ and measuring activity at selected times up to $240 \mathrm{~min}$.

Inhibitor studies. The effects of sodium azide, EDTA, thioglycolic acid and hydroxylamine on enzyme activity were tested using ABTS as substrate after pre-incubating the enzyme for $10 \mathrm{~min}$ (at $25^{\circ} \mathrm{C}$ ) with the various inhibitors before the addition of substrate.

Absorption spectra. For the spectroscopic characterization $0 \cdot 2 \mathrm{mg} \mathrm{ml}^{-1}$ purified laccase, in $25 \mathrm{mM}$ sodium acetate buffer, $\mathrm{pH} 5$ was used. The absorption spectra was determined between 190 and $1000 \mathrm{~nm}$ at $25^{\circ} \mathrm{C}$ using a Beckman Du 640 spectrophotometer. The ratio of $A_{280 / 605}$ was used for characterization of the copper content of laccase.

Nucleotide sequence accession number. The sequence of the Pleurotus sajor-caju laccase 4 gene (lac4) reported here has been assigned the accession no. AF 297228 in the GenBank database.

\section{RESULTS}

\section{Cloning and sequence analysis of the Ple. sajor-caju laccase isozyme Psc lac4 gene}

RNA-PCR using primers designed from the previously cloned Pox1 laccase gene of Pleurotus ostreatus (pLac4 ATG Fw and pLac4 Rev; Table 1) (Giardina et al., 1995) were used to clone the full-length cDNA lac4 gene. A single cDNA PCR product of $1695 \mathrm{bp}$, with a $1603 \mathrm{bp}$ open reading frame was obtained. The deduced amino acid sequence of Psc Lac4 encodes a protein of 533 amino acids. All of the expected copper ligands (10 His residues and one Cys residue) are present in the Psc Lac4. The translation initiation site for Psc Lac4 is ACGATGT, which is consistent with the consensus sequence for higher eukaryotes, RNNATGG (Kozak, 1981), where $R$ is a purine. Translation of $69 \mathrm{bp}$ starting at the ATG codon results in a 23 aa putative signal peptide, which shows the typical structure of sorting for secreted proteins in eukaryotes and is followed by a sequence that could act as a peptidase recognition site (Von Heijne, 1986). The core region of the putative signal peptide is predominantly hydrophobic, which is again characteristic of eukaryotic signal peptides. The predicted amino acid sequence of Psc Lac4 exhibited a high degree of similarity to Pox2 from Ple. ostreatus (Palmieri et al., 1997), as well as a high degree of similarity with corresponding sequences of other basidiomycete laccases genes, including those of other Pleurotus and Trametes species, ranging from 52 to $99 \%$ identity at the amino acid level (Soden, 2002). 


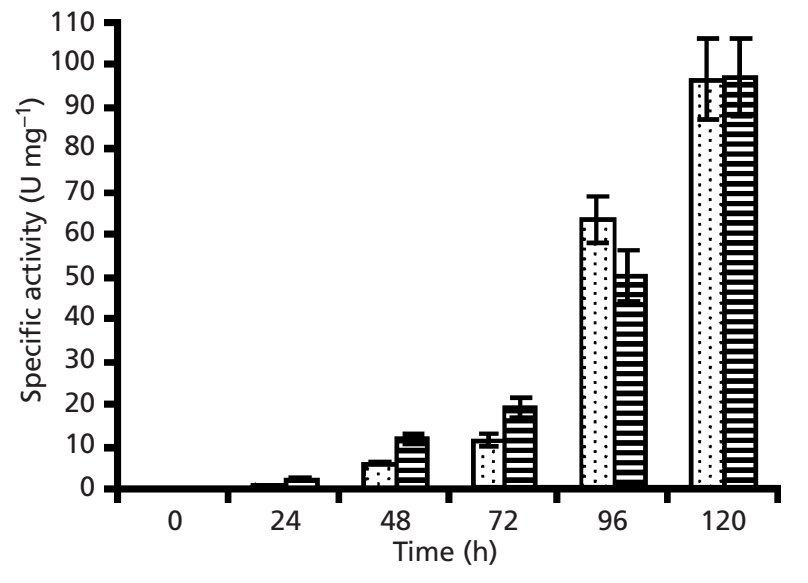

Fig. 1. Comparison of laccase expression from Pic. pastoris strains GS115 and KM71. Mean values were obtained by using three separate transformants for each strain. Methanol $(0.5 \%)$ was added daily to cultures. Dotted bars, GS115; lined bars, KM71.

Identity to the laccase genes of the ascomycete fungi was lower at between 14 and $24 \%$, while the $p p o A$ 'bacterial laccase' gene from the prokaryote Mariomonas mediterranea (Sanchez-Amat et al., 2001) exhibited $11 \%$ identity.

\section{Heterologous expression}

Both the pPIC3.5-lac4 and pPIC9-lac4-SS (without the native 23 aa putative signal peptide) constructs were linearized with StuI and transformed into electrocompetent Pic. pastoris GS115 and KM71 cells. Green coloured zones on MM plates were observed with the pPIC3.5-lac4 transformants after $24 \mathrm{~h}$, while colour was observed around the pPIC9-lac4-SS transformants after 7 days. When both transformants were subsequently grown in liquid cultures, intracellular laccase activity was noted for pPIC9-lac4-SS but not for pPIC3.5-lac4, indicating that the native signal sequence is required for effective secretion of the recombinant laccase (data not shown). Subsequent experiments were then conducted with the pPIC3.5-lac4 construct. No visible difference in colony growth rates was observed between the proteasepositive GS115 and the protease-negative KM71 strains transformed with pPIC3.5-lac4 on MM plates when methanol was used as the carbon source. This was confirmed in liquid cultures where the specific activity of laccase was almost identical for both strains after $120 \mathrm{~h}$ (Fig. 1). A Pic. pastoris GS115 strain transformed with pPIC3.5-lac4 was used in all subsequent growth experiments.

A time-course analysis was performed with samples being taken after $0,48,96$ and $144 \mathrm{~h}$ to examine protein production in Pic. pastoris GS115 (pPIC3.5-lac4) by SDS-PAGE (Fig. 2a). A band corresponding to approximately $59 \mathrm{kDa}$ was observed after $48 \mathrm{~h}$ and became more pronounced at the later time points tested. Confirmation that this band corresponded to Psc Lac4

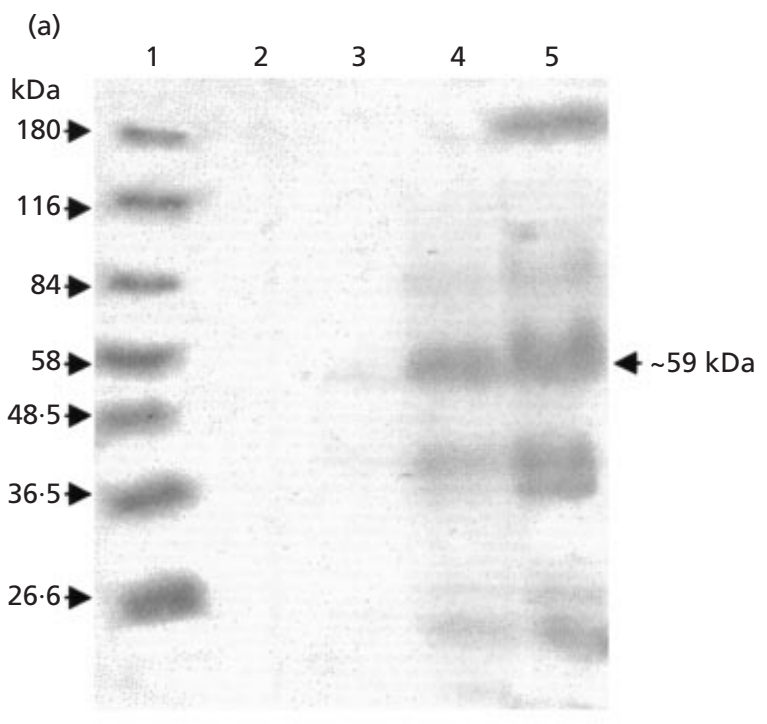

(b) $\quad 1 \quad 2 \quad 3 \quad 4$
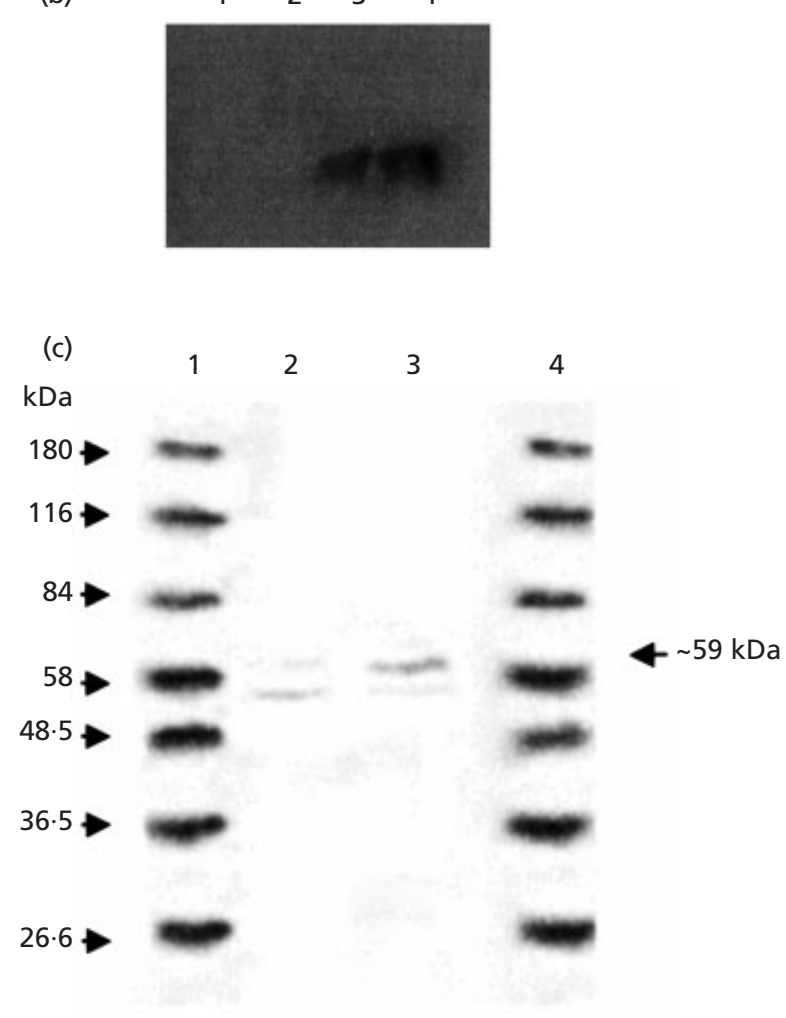

Fig. 2. (a) SDS-PAGE of a time-course analysis of laccase production by Pic. pastoris GS115 (pPIC3.5-lac4) in buffered minimal medium with $0.8 \%$ alanine. Lane 1 contains molecular mass markers. Lanes 2, 3, 4 and 5 represent protein samples collected after $0,2,4$ and 6 days respectively. The arrow indicates the molecular mass of Psc Lac4 ( $\sim 59 \mathrm{kDa})$. (b) Immunoblot analysis of the extracellular proteins $(10 \mu \mathrm{g}$ per lane) in (a) above. Lanes 1-4 represent samples taken after 0,2 , 4 and 6 days respectively. (c) SDS-PAGE analysis of native and deglycosylated Psc Lac4 laccase from Pic. pastoris GS115 (pPIC3.5-lac4). Lanes 1 and 4 contain molecular mass markers, lane 2 contains $10 \mu \mathrm{g}$ deglycosylated laccase $(\sim 55 \mathrm{kDa})$, lane 3 contains $10 \mu \mathrm{g}$ purified native laccase $(\sim 59 \mathrm{kDa})$. 
Table 2. Purification of Psc Lac4 expressed in Pic. pastoris

\begin{tabular}{|c|c|c|c|c|c|c|c|}
\hline Purification step & $\begin{array}{l}\text { Vol. of fraction } \\
(\mathrm{ml})\end{array}$ & $\begin{array}{l}\text { Protein concn } \\
\quad\left(\mathrm{mg} \mathrm{ml}^{-1}\right)\end{array}$ & $\begin{array}{l}\text { Enzyme concn } \\
\quad\left(\mathrm{U} \mathrm{ml}^{-1}\right)\end{array}$ & $\begin{array}{l}\text { Specific activity } \\
\quad\left(\mathrm{U} \mathrm{mg}^{-1}\right)\end{array}$ & $\begin{array}{c}\text { Total amount } \\
(\mathrm{U})\end{array}$ & Yield (\%) & $\begin{array}{l}\text { Purification factor } \\
\text { (fold) }\end{array}$ \\
\hline Crude cell-free extract & 1800 & $0 \cdot 11$ & $10 \cdot 2$ & $92 \cdot 7$ & $23 \cdot 9$ & 100 & $1 \cdot 00$ \\
\hline Concentration Amicon (10 kDa) & 3 & $26 \cdot 14$ & 5180 & $198 \cdot 2$ & $17 \cdot 5$ & $84 \cdot 6$ & $2 \cdot 14$ \\
\hline Ion exchange: Q-Sepharose & 5 & 0.5 & 1050 & 2100 & $9 \cdot 8$ & $28 \cdot 6$ & $22 \cdot 65$ \\
\hline
\end{tabular}


Table 3. Substrate specificity tests

\begin{tabular}{|c|c|c|c|}
\hline & $K_{\mathrm{m}}(\mathrm{mM})$ & $10^{4} \times k_{\text {cat }}\left(\min ^{-1}\right)$ & $\begin{array}{c}10^{4} \times k_{\mathrm{cat}} / K_{\mathrm{m}} \\
\left(\mathrm{min}^{-1} \mathrm{mM}^{-1}\right)\end{array}$ \\
\hline ABTS & $2 \cdot 5$ & $7 \cdot 4$ & $2 \cdot 96$ \\
\hline DMP & $0 \cdot 12$ & $5 \cdot 8$ & $48 \cdot 33$ \\
\hline Guaiacol & 0.066 & $0 \cdot 68$ & $10 \cdot 3$ \\
\hline Syringaldazine & $0 \cdot 28$ & $3 \cdot 5$ & $12 \cdot 5$ \\
\hline
\end{tabular}

came from a Western blot that was performed on samples taken from the time-course analysis, using antiPle. eryngii laccase antibodies (Muñoz et al., 1997). Immunoblot analysis revealed that Psc Lac4 crossreacted immunologically with the Ple. eryngii laccase antibody, with the strongest reaction corresponding to day 6 , the day of maximal laccase activity (Fig. 2b).

\section{Purification of laccase from Pic. pastoris culture broth}

The recombinant Psc Lac4 protein was purified from $1.8 \mathrm{l}$ culture broth following $120 \mathrm{~h}$ growth in BMM medium. During purification ultrafiltration with a membrane with a $10 \mathrm{kDa}$ molecular mass cutoff enriched for laccase by $2 \cdot 14$-fold. Subsequent purification steps involved Sephadex G-75 chromatography at $\mathrm{pH} 5$, resulting in a 5.7-fold purification, and finally QSepharose chromatography at $\mathrm{pH} 8 \cdot 5$, with one active peak being eluted. The purified protein had an activity of $1050 \mathrm{U} \mathrm{ml}^{-1}$, with a specific activity of 2100 units $\mathrm{mg}^{-1}$. A summary of the purification steps is shown in Table 2.

\section{Characterization of the purified laccase}

Molecular mass. The calculated molecular mass of 54431 Da from the deduced amino acid sequence for Psc Lac4, correlates well with the apparent molecular mass of approximately $59 \mathrm{kDa}$ determined by SDS-PAGE (Fig. 2c, lane 3). Psc Lac4 treated with N-glycosidase F migrated to a position on the SDS-PAGE gel that corresponded to an apparent molecular mass of approximately $55 \mathrm{kDa}$, indicating a carbohydrate content of around $7 \%$ (Fig. 2c, lane 3). Potential $N$ glycosylation sites (Asn-Xxx-Ser/Thr) (Gavel \& Von Heijne, 1990) can be recognized at positions 241 and 467 of the amino acid sequence. The calculated isoelectric point $(\mathrm{pI})$ is $4 \cdot 38$.

\section{Catalytic properties}

(a) Substrate range and specificity. The purified Psc Lac4 oxidized the common laccase substrates ABTS, DMP, syringaldazine and guaiacol with $K_{\mathrm{m}}$ values ranging from 2.5 to $0.066 \mathrm{mM}$ for ABTS and guaiacol respectively. Similarly, ABTS exhibited the highest $k_{\text {cat }}$ values $\left(7 \cdot 4 \times 10^{4} \min ^{-1}\right) \quad$ whereas DMP demonstrated the highest $k_{\text {cat }} / K_{\mathrm{m}}$ value $\left(4.83 \times 10^{5} \mathrm{~min}^{-1} \mathrm{mM}^{-1}\right)$ (Table $3)$. The kinetic parameters for guaiacol were determined in the presence of $10 \%$ acetone, due to its low solubility

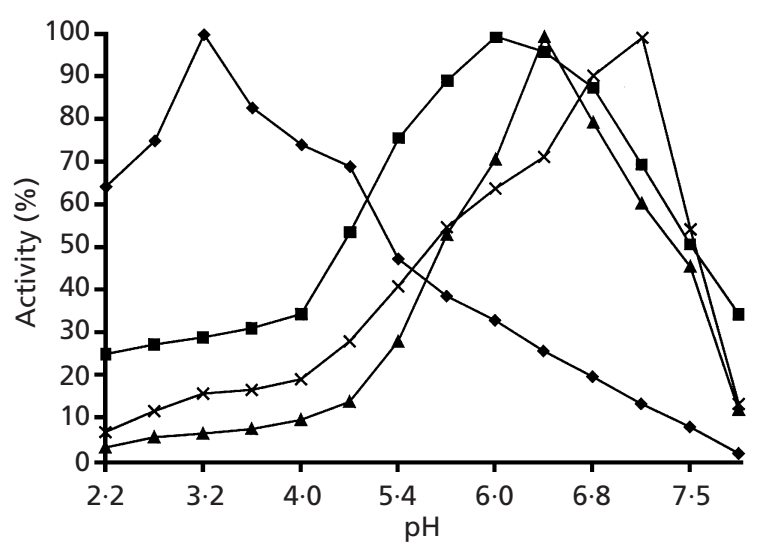

Fig. 3. Effect of $\mathrm{pH}$ on laccase activity with different substrates ABTS $(\diamond)$, DMP $(\boldsymbol{\square})$, syringaldazine $(\boldsymbol{\Delta})$ and guaiacol $(\times)$. Values represent the mean of three separate determinations. The standard deviation was less than $10 \%$.

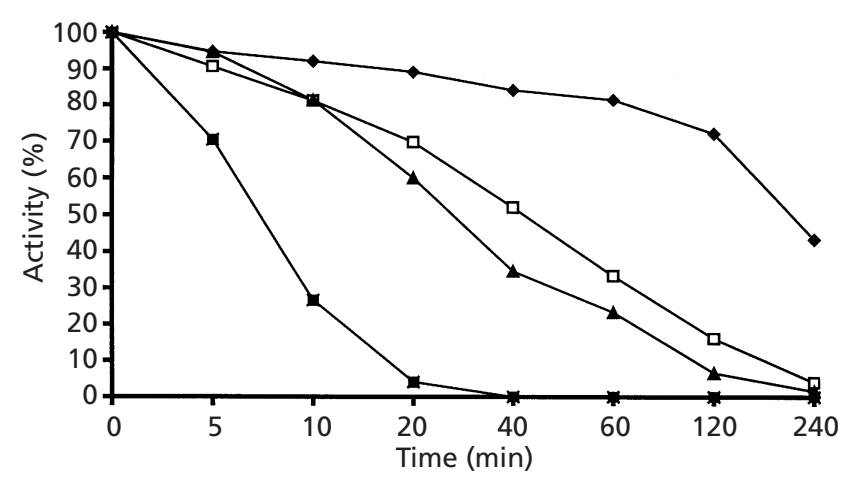

Fig. 4. Effect of temperature on the stability of the recombinant Psc Lac4, with assays being conducted at $\mathrm{pH} 7$ using $A B T S$ as substrate. Values represent the mean of three separate determinations. The standard deviation was less than $8 \% . \bullet, 35^{\circ} \mathrm{C} ; \square, 45^{\circ} \mathrm{C} ; \boldsymbol{\Delta}, 55^{\circ} \mathrm{C} ; \boldsymbol{\square}, 65^{\circ} \mathrm{C}$.

in $\mathrm{dH}_{2} \mathrm{O}$. DL-Dopa did not act as a substrate for the recombinant laccase (Table 3 ).

(b) pH optimum and stability. The activity of purified Psc Lac4 as a function of $\mathrm{pH}$ was determined. The optimum $\mathrm{pH}$ differs for each individual substrate assayed from $3 \cdot 3,6 \cdot 0,6 \cdot 5$ and 7 for ABTS, DMP, syringaldazine and guaiacol respectively, with all substrates demonstrating a broad activity over a wide $\mathrm{pH}$ range (Fig. 3 ). At $4{ }^{\circ} \mathrm{C}$, 


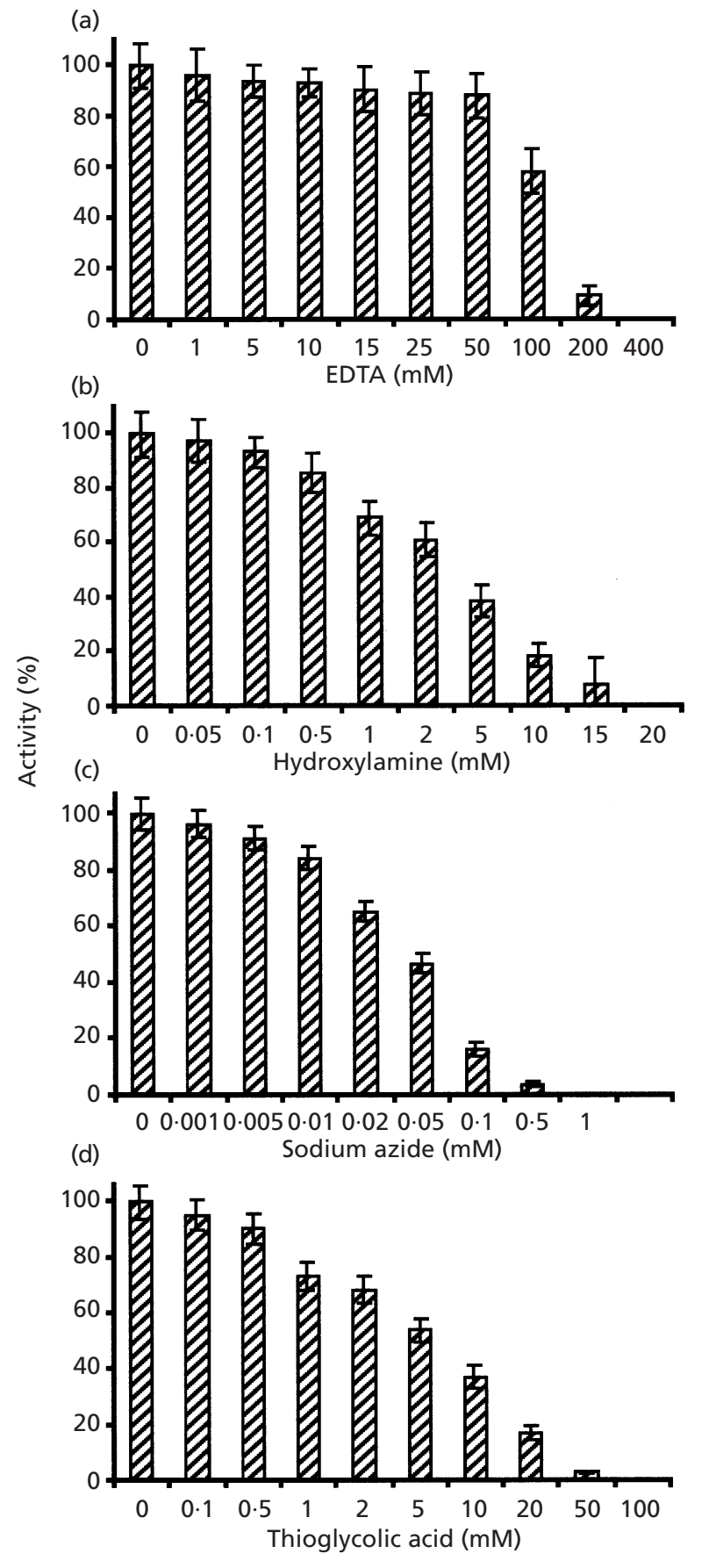

Fig. 5. Effect of various enzyme inhibitors on Psc Lac4 laccase activity. All experiments were conducted in triplicate with ABTS as the enzyme substrate.

Psc Lac 4 was stable for at least 5 h between $\mathrm{pH} 6$ and $\mathrm{pH}$ 8. Over the same period of time, the activity decreased to approximately $80 \%, 70 \%$ and $64 \%$ of the original value when the enzyme was incubated at $\mathrm{pH} 5$, $\mathrm{pH} 3$ and $\mathrm{pH} 9$, respectively. At $25^{\circ} \mathrm{C}$, the $\mathrm{pH}$ stability of Psc Lac 4 was reduced. While the activity was still stable for at least $5 \mathrm{~h}$ at $\mathrm{pH} 7$, over the same period of time residual activity decreased to approximately $30 \%$,
$2 \%$ and $50 \%$ of the original value when the enzyme was incubated at $\mathrm{pH} 5, \mathrm{pH} 3$ and $\mathrm{pH} 9$, respectively.

(c) Effects of temperature on activity. The optimal temperature for Psc Lac4 activity was $35^{\circ} \mathrm{C}$ with ABTS as substrate. Thermal stability studies ranging from $35^{\circ} \mathrm{C}$ to $65^{\circ} \mathrm{C}$ were carried out at $\mathrm{pH} 7$ (Fig. 4). Psc Lac4 was relatively stable after $1 \mathrm{~h}$ at $35^{\circ} \mathrm{C}$; however, over the same period of time residual activity decreased to approximately $35 \%$ and $25 \%$ of the original value when incubated at $35^{\circ} \mathrm{C}$ and $45^{\circ} \mathrm{C}$ respectively, while no detectable activity was observed after $1 \mathrm{~h}$ at $65^{\circ} \mathrm{C}$.

(d) Inhibitor studies. The effect of various enzyme inhibitors on laccase activity was assessed. Oxidation of ABTS was unaffected by low levels of EDTA $(<50 \mathrm{mM})$; however, concentrations above $100 \mathrm{mM}$ were inhibitory (Fig. 5a). Total inhibition was observed with $20 \mathrm{mM}$ hydroxylamine (Fig. $5 \mathrm{~b}$ ), $0.5 \mathrm{mM}$ sodium azide (Fig. 5c) and $100 \mu \mathrm{M}$ thioglycolic acid (Fig. 5d).

(e) Copper content. The absorption spectrum of Psc Lac4 is characterized by the lack of a peak around $600 \mathrm{~nm}$ (data not shown). This peak is representative of the type 1 copper site, which gives purified laccase its characteristic blue colour, which may explain the colourless nature of the purified Psc Lac4.

\section{DISCUSSION}

We have previously reported on the cloning of four laccase isozyme genes from the edible fungus Ple. sajorcaju (Soden \& Dobson, 2001). Here we report on the cloning of the full-length gene for one of these isozyme genes, namely Psc lac4, and on its subsequent expression in the heterologous host Pic. pastoris. Primers based on the previously cloned Pox1 laccase gene (Giardina et al., 1995) were used to clone the Psc lac4 gene of 1695 bp, with an open reading frame of $1603 \mathrm{bp}$. The deduced pLac4 amino acid sequence encodes a protein of 533 amino acids, which contains the 10 highly conserved histidine residues which act as copper ligands (Thurston, 1994), and also exhibits a high degree of similarity to other laccases and ascorbate oxidases, from basidiomycete and ascomycete fungi, and plants, particularly in the carboxy-terminus copper-binding site. This similarity is reflected in the fact that Western blot analysis revealed Psc Lac4 to be immunologically related to Ple. eryngii laccase I (Fig. 2b). Analysis of the predicted 23 aa signal peptide of Psc Lac4 reveals a potential peptidase recognition site of Thr, His, Ala, Ala with the most likely cleavage site being between the two Ala residues. This follows the $-3,-1$ rule of Von Heijne (1986), which predicts that there is a small uncharged amino acid residue (Ala) at position -1 relative to the cleavage site and the absence of an aromatic charged or large and polar residue in position -3 .

It has been proposed that for the type 1 copper ligand, the amino acid residue located 10 amino acids downstream of the conserved cysteine affects the redox potential of the type 1 copper in the active site (Canters \& Gilardi, 1993), thus providing a basis for assigning 
laccases to class 1 (Met), 2 (Leu) or 3 (Phe) (Eggert et al., 1998). Psc Lac4 is a class 2 laccase based on this classification. Subsequent analysis of the purified recombinant Psc Lac4 by means of a UV-visible wavelength scan revealed the absence of a peak around $600 \mathrm{~nm}$, the presence of which represents a T1 copper site and is believed to be responsible for the blue colour of the enzyme. To examine whether the absence of this peak might be due to copper depletion during the purification process, the scan was also conducted in the presence of $0 \cdot 2 \mathrm{mM} \mathrm{CuSO}_{4}$, without altering the result. The purified Psc Lac4 protein was indeed white/yellow in colour and in this regard is similar to previously characterized 'white laccases' from Agaricus bisporus (Wood, 1980) and Ple. ostreatus (Palmieri et al., 1997).

\section{Heterologous expression}

We chose the yeast Pic. pastoris as the heterologous host to express Psc Lac4 as it has been previously used in the expression of a wide variety of proteins (Cereghino \& Cregg, 2000). Pic. pastoris is known to secrete foreign protein in the presence of low levels of native proteins, most importantly proteinases, thus helping simplify the purification procedure. In addition, the inducibility of the expression system is particularly important where the strong regulated alcohol oxidase 1 (AOX1) promoter, which is repressed by glucose and most other carbon sources, is induced $>1000$-fold when cells are shifted to methanol as the sole carbon source (Cereghino \& Cregg, 1999). Previous work on laccase expression in Pic. pastoris has identified temperature, $\mathrm{pH}$ and oxygen as factors that affect laccase production. Cassland \& Jönsson (1999) have reported that production of active enzyme is favoured by lower cultivation temperatures, with laccase activity being 16 -fold higher after 3 days at $19{ }^{\circ} \mathrm{C}$ when compared to $28^{\circ} \mathrm{C}$, with the same being true for laccase production in Sac. cerevisiae.

In this work cultures were first grown in BGM media at $28^{\circ} \mathrm{C}$ and then transferred to $\mathrm{BMM}$ media at $20^{\circ} \mathrm{C}$. At $20^{\circ} \mathrm{C}$ an $\mathrm{OD}_{600}$ of approximately 20 (initially inoculated at an $\mathrm{OD}_{600}$ of 1) after $96 \mathrm{~h}$ was obtained, with a laccase activity of 64 units (mg protein $)^{-1}$ (Fig. 1). Previous work has also reported that the $\mathrm{pH}$ of unbuffered growth media decreases from 5 to approximately 3 within the first day of growth and this has a detrimental effect on recombinant laccase levels (Gelo-Pujic et al., 1999; Jönsson et al., 1997). This may be due at least in part by the activation of acidic proteases and the loss of enzyme stability at a lower $\mathrm{pH}$. The use of buffered $\mathrm{BMM}$ media only maintains the $\mathrm{pH}$ for short periods of time and has been shown to be inadequate unless the $\mathrm{pH}$ is raised during growth of Pichia (Jönsson et al., 1997). However O'Callaghan et al. (2002) have reported the successful use of alanine as an additional buffer component to BMM. In this work we used $0.8 \%$ alanine in all $\mathrm{BMM}$ growth media and the $\mathrm{pH}$ remained at the initial $\mathrm{pH}$ of 6 for up to $144 \mathrm{~h}$ post-inoculation. In addition, all cultures were grown in baffled flasks with shaking to ensure an adequate supply of oxygen, which is necessary for the oxidation of methanol to formaldehyde by alcohol oxidase.

The native signal peptide of Psc Lac4 was effective for directing both the secretion and proper proteolytic maturation of lac4 expressed in Pic. pastoris. In contrast, use of the Sac.cerevisiae $\alpha$-factor secretion signal peptide resulted in intracellular production of active laccase, as indicated by the presence of a dark green colour ABTS $^{+}$ radical) localized within the colonies transformed with pPIC9-lac4-SS. This was confirmed by assaying cell pellets of liquid cultures that had been washed and ruptured with acid-washed glass beads (Invitrogen, 1998). This intracellular production of laccase may be due to the inappropriate processing of the fusion protein.

Other studies which compare the Sac. cerevisiae $\alpha$-factor signal peptide to native fungal signal peptides for secretion of recombinant laccase have reported differing findings.

While the amount of laccase produced was seven-fold higher when the native secretion signal was used instead of the $\alpha$-factor secretion signal of pPIC9 for the $T$. versicolor lccl gene product (Jönsson et al., 1997), similar levels of laccase activity were observed for the Lac1 isoform from Pyc. cinnabarinus when either the native or yeast leader sequence was employed (Otterbein et al., 2000). Thus the use of native laccase signal sequences from fungi such as Ple. sajor-caju or $T$. versicolor may be a viable alternative to the $\alpha$-factor signal peptide for the expression and subsequent secretion of other recombinant proteins in Pic. pastoris. This would be of relevance to the commercial production of numerous recombinant proteins in the Pichia system, given that the use of the $\alpha$-mating factor signal peptide is subject to proprietary rights. Due to the generally regarded as safe (GRAS) status of Ple. sajorcaju, the use of native laccase signal sequences from this fungus may be particularly relevant to recombinant proteins with therapeutic applications.

Several fungal laccase genes have previously been cloned and heterologously expressed in Trichoderma reesei (Saloheimo \& Niku-Paavola, 1991), Sac. cerevisiae (Cassland \& Jönsson, 1999), A. niger (Record et al., 2002) and A. oryzae (Yaver et al., 1996; Berka et al., 1997). The level of Psc Lac4 laccase produced here in Pic. pastoris is $4.85 \mathrm{mg} \mathrm{l}^{-1}$ and is comparable to levels previously reported in yeast which were around $5 \mathrm{mg}$ $1^{-1}$, while fungal hosts resulted in levels of $10-20 \mathrm{mg} \mathrm{l}^{-1}$. The highest levels obtained to date were those with a Pyc. cinnabarinus laccase expressed in A. oryzae where levels of 8-135 $\mathrm{mg} \mathrm{l}^{-1}$ were obtained (Yaver et al., 1999). While the laccase levels obtained here are not comparable with those obtained in A. oryzae, they are nonetheless sufficient to allow the biochemical characterization of the enzyme.

\section{Biochemical characterization}

The level of Psc Lac4 expression reported here $\left(4.85 \mathrm{mg} \mathrm{l}^{-1}\right)$ enabled the purification and the first biochemical characterization of a fungal laccase isozyme 
expressed in Pic. pastoris. It appears to be a monomeric protein of molecular mass of approximately $59 \mathrm{kDa}$, with a calculated $\mathrm{pI}$ of 4.38 . The purified Psc Lac4 oxidized typical laccase substrates such as ABTS and syringaldazine very efficiently as is evident from the high values determined for the catalytic constants $k_{\text {cat }}$ and the catalytic efficiencies $k_{\text {cat }} / K_{\mathrm{m}}$ for some selected substrates (Table 3). The introduction of a second methoxyl group as found in DMP resulted in an almost 11-fold increase in $k_{\text {cat }} / K_{\mathrm{m}}$ as compared to the monomethoxylated substrate guaiacol. A likely explanation for this is the strong electron-donating effect of the two methoxyl substituents and the favourable redox potential of the substrate DMP (Xu et al., 1996).

In terms of activity, the optimal $\mathrm{pH}$ was $3 \cdot 3,6,6 \cdot 5$ and 7 with ABTS, DMP, syringaldazine and guaiacol as substrates respectively. Psc Lac4 displays certain similarities to Pox2, a previously characterized laccase isozyme from Ple. ostreatus (Palmeri et al., 1997) to which it shows a high degree of similarity at the deduced amino acid level. These similarities include molecular mass $(\sim 59 \mathrm{kDa})$ and $\mathrm{pH}$ optimum with ABTS as substrate; however, Pox2 has a higher temperature optimum than Psc Lac4. Indeed the stability of Psc Lac4 as a function of temperature was low relative to other laccases. One possible explanation is the level of glycosylation of Psc Lac4 following expression in Pic. pastoris $(\sim 7 \%)$, which may be lower than when the protein is expressed in Pleurotus given that proteins secreted by Pic. pastoris are known to be less extensively glycosylated and that carbohydrate content has been proposed to protect laccases from Botrytis cinerea (Slomczynski et al., 1995) and T. versicolor from hightemperature denaturation. Furthermore, it has been proposed that the expression of an A. niger phytase gene in Sac. cerevisiae resulted in an increased level of glycosylation for the phytase protein and a corresponding increase in temperature stability (Han et al., 1999). Other similarities between Pox2 and Psc Lac4 include similar patterns of $\mathrm{pH}$ stability at $25^{\circ} \mathrm{C}$ with both remaining unaltered at $\mathrm{pH} 7$ but decreasing in stability as the $\mathrm{pH}$ decreased. Psc Lac4 was strongly inhibited by the copper chelating agents, sodium azide and thioglycolic acid, but not by EDTA, which is typical of other previously characterized laccases.

In conclusion, we have demonstrated the use of the heterologous Pic. pastoris expression system to produce sufficient quantities of recombinant Psc Lac4 protein to allow its biochemical characterization. While several laccases have been cloned, their biochemical characterization has been difficult due to the low levels of expression in their native systems, such as for example the Pox1 laccase in Ple. ostreatus (Giardina et al., 1995). If we are to gain a fuller understanding of the structurefunction relationships of fungal laccases with respect to substrate specificity, $\mathrm{pH}$ profile and redox potential, then experiments involving site-directed mutagenesis similar to that which has already been undertaken with a T.versicolor laccase (Gelo-Pujic et al., 1999) need to be conducted. From the work presented here it appears that
Pic. pastoris would provide an ideal heterologous host in which to express these mutants, with the system providing sufficient quantities of recombinant enzyme to allow subsequent biochemical characterization of mutant proteins. In addition it is clear that given the (GRAS) status of both Ple. sajor-caju and Pic. pastoris the production of a 'food-grade' fungal laccase using this system would have potential utility in several industrial applications, particularly in the food biotechnology sector.

\section{ACKNOWLEDGEMENTS}

D.S. was in receipt of a research studentship from Bioresearch Ireland.

\section{REFERENCES}

Agematu, H., Kominatu, K., Shibamoto, N., Yoshioka, T., Nishida, H., Okamoto, R., Shin, T. \& Murao, S. (1993). Transformation of cephalosporanic acid into new cephalosporin derivatives. Biosci Biotechnol. Biochem 57, 1387-1388.

Alexandre, G. \& Zhulin, I. B. (2000). Laccases are widespread in bacteria. Trends Biotechnol 18, 41-42.

Altschul, S. F., Gish, W., Miller, W., Myers, E. W. \& Lipman, D. J. (1990). Basic local alignment search tool. J Mol Biol 215, 403-410.

Aramayo, R. \& Timberlake, W. E. (1990). Sequence and molecular structure of the Aspergillus nidulans yA (laccase I) gene. Nucleic Acids Res 18, 3415.

Ausubel, F. M., Brent, R., Kingston, E., Moore, D. D., Seidman, J. G., Smith, J. A. \& Struhl, K. (1996). Current Protocols in Molecular Biology. New York: Wiley.

Baker, W. L., Subapathy, K., Vibat, M. \& Lonergan, G. (1996). Laccase catalyses formation of an inadamine dye between 3methyl-2-benzothiazolinone hydrazone and 3-dimethylamonobenzoic acid. Enzyme Microb Technol 18, 90-94.

Berka, R. M., Schneider, P., Golightly, E. J., Brown, S. H., Madden, M., Brown, K. M., Halkier, T., Mondorf, K. \& Xu, F. (1997). Characterization of the gene encoding an extracellular laccase of Myceliophthora thermophila and analysis of the recombinant enzyme expressed in Aspergillus oryzae. Appl Environ Microbiol 63, 3151-3157.

Bourbonnais, R., Paice, M. G., Reid, I. D., Lanthier, P. \& Yaguchi, M. (1995). Lignin oxidation by laccase enzymes from Trametes versicolor and the role of the mediator in 2,2'-azinobis(3ethylbenzthiazoline-6-sulphonate) kraft lignin depolymerization. Appl Environ Microbiol 61, 1876-1880.

Bourbonnais, R., Paice, M. G., Leech, D. \& Freiermuth, B. (1997). Reactivity and mechanism of laccase mediators for pulp deligninification. In 1997 Biological Science Symposium, pp. 335-338. Atlanta, GA: TAPPI Press.

Bradford, M. M. (1976). A rapid and sensitive method for the quantitation of microgram quantities of protein utilizing the principle of protein-dye binding. Anal Biochem 72, 248-254.

Brown, M. A., Zhao, Z. \& Mauk, A. G. (2002). Expression and characterization of a recombinant multi-copper oxidase: laccase IV from Trametes versicolor. Inorg Chim Acta 331, 232-238.

Canters, G. H. \& Gilardi, G. (1993). Engineering type 1 copper sites in proteins. FEBS Lett 325, 39-48.

Cassland, P. \& Jönsson, L. J. (1999). Characterization of a gene encoding Trametes versicolor laccase A and improved hetero- 
logous expression in Saccharomyces cerevisiae by decreased cultivation temperature. Appl Microbiol Biotechnol 52, 393-400.

Cereghino, G. P. L. \& Cregg, J. M. (1999). Applications of yeasts in biotechnology: protein production and genetic analysis. Curr Opin Biotechnol 10, 422-427.

Cereghino, G. P. L. \& Cregg, J. M. (2000). Heterologous protein expression in the methylotrophic yeast Pichia pastoris. FEMS Microbiol Rev 24, 45-66.

Choi, G. H., Larson, T. G. \& Nuss, D. L. (1992). Molecular analysis of the laccase from the chestnut blight fungus and selective suppression of its expression in an isogenic hypovirulent strain. Mol Plant-Microbe Interact 5, 119-128.

Collins, P. J., Kotterman, M. J. J., Field, J. A. \& Dobson, A. D. W. (1996). Oxidation of anthracene and benzo[a]pyrene by laccases from Trametes versicolor 290. Appl Environ Microbiol 62, 4563-4567.

Eggert, C., Temp, U. \& Eriksson, K. E. (1997). Laccase is essential for lignin degradation by the white rot fungus Pycnoporus cinnabarinus. FEBS Lett 407, 89-92.

Eggert, C., LaFayette, P. R., Temp, U., Eriksson, K. E. L. \& Dean, J. F. D. (1998). Molecular analysis of a laccase gene from the whiterot fungus Pycnoporus cinnabarinus. Appl Environ Microbiol 64, 1766-1772.

Eriksson, K. E. L., Blanchette, R. A. \& Ander, P. (1990). Biochemistry of lignin degradation. In Microbial and Enzymatic Degradation of Wood and Wood Components, pp. 253-307. Edited by K. E. L. Eriksson, A. Blanchette \& P. Ander. Berlin: Springer.

Field, J. A., De Jong, E., Feijoo-Costa, G. \& De Bont, J. A. M. (1993). Screening for ligninolytic fungi applicable to the biodegradation of xenobiotics. Trends Biotechnol 58, 2219-2226.

Gavel, Y. \& Von Heijne, G. (1990). Sequence differences between glycosylated and non-glycosylated Asn-X-Thr/Ser acceptor sites: implications for protein engineering. Protein Eng 3, 433-442.

Gelo-Pujic, M., Hyug-Han, K., Butlin, N. G. \& Palmore, G. T. R. (1999). Electrochemical studies of a truncated laccase produced in Pichia pastoris. Appl Environ Microbiol 65, 5515-5521.

Ghindilis, A. L., Makeover, A., Bauer, C. G., Bier, F. F. \& Scheller, F. W. (1995). Determination of p-aminophenol and catecholamines at picomolar concentrations based on recycling enzyme amplification. Anal Chim Acta 304, 25-31.

Gianfreda, L., Xu, F. \& Bollag, J.-M. (1999). Laccases: a useful group of oxidoreductive enzymes. Biorem J 3, 1-25.

Giardina, P., Cannio, R., Martirani, L., Marzullo, L., Palmieri, G. \& Sannia, G. (1995). Cloning and sequencing of a laccase gene from the lignin-degrading basidiomycete Pleurotus ostreatus. Appl Environ Microbiol 61, 2408-2413.

Gromroff, E. D., Treiser, U. \& Beck, C. F. (1989). Three lightinducible heat shock genes of Chlamydomonas reinhardtii. Mol Cell Biol 9, 3911-3918.

Han, Y., Wilson, D. B. \& Lei, X. G. (1999). Expression of an Aspergillus niger phytase gene (phyA) in Saccharomyces cerevisiae. Appl Environ Microbiol 65, 1915-1918.

Harkin, J. M., Larsen, M. J. \& Obst, J. R. (1974). Use of syringaldazine for detection of laccase in sporophores of wood rotting fungi. Mycologia 66, 469-476.

Higgins, D. G. \& Sharp, P. M. (1989). Fast and sensitive multiple sequence alignments on a microcomputer. CABIOS 5, 151-153.

Hoshida, H., Nakao, M., Kanazawa, H., Kubo, K., Hakukawa, T., Morimasa, K., Akada, R. \& Nishizawa, Y. (2001). Isolation of five laccase gene sequences from the white-rot fungus Trametes sanguinea by PCR, and cloning, characterisation and expression of the yeast cDNA in yeasts. J Biosci Bioeng 92, 372-380.

Invitrogen (1998). Multi-copy Pichia Expression Kit Manual, version C. Carlsbad, CA: Invitrogen.

Jönsson, L. J., Sjöström, K., Häggström, I. \& Nyman, P. O. (1995). Characterization of a laccase gene from the white rot fungus Trametes versicolor and structural features of basdiomycete laccases. Biochim Biophys Acta 1251, 210-215.

Jönsson, L. J., Saloheimo, M. \& Penttila, M. (1997). Laccase from the white-rot fungus Trametes versicolor: cDNA cloning of lcc1 and expression in Pichia pastoris. Curr Genet 32, 425-430.

Kawai, S., Umezawa, T. \& Higuchi, T. (1989). Oxidation of methoxylated benzyl alcohols by laccase of Coriolus versicolor in the presence of syringaldahyde. Wood Res 76, 10-16.

Kojima, Y., Tsukuda, Y., Kawai, Y., Tsukamoto, A., Sugiura, J., Sakaino, M. \& Kita, Y. (1990). Cloning, sequence analysis and expression of ligninolytic polyphenoloxidase genes of the whiterot basidiomycete Coriolus hirsutus. I Biol Chem 265, 15224-15230

Kozak, M. (1981). Possible role of flanking nucleotides in recognition of AUG initiator codon by eukaryotic ribosomes. Nucleic Acids Res 12, 857-872.

Laemmli, U. K. (1970). Cleavage of structural proteins during the assembly of the head of bacteriophage T4. Nature, 227, 680-685.

Larsson, S., Cassland, P. \& Jönsson, L. J. (2001). Development of a Saccharomyces cerevisiae strain with enhanced resistance to phenolic fermentation inhibitors in ligninocellulose hydrolysates by heterologous expression of laccase. Appl Environ Microbiol 67, 1163-1170.

Leatham, G. F. \& Stahmann, M. A. (1981). Studies on the laccase of Lentinus edodes: specificity, localization and association with the development of fruiting bodies. J Gen Microbiol 125, 147-157.

Malkin, R. \& Malmstrom, B. G. (1970). The state and function of copper in biological systems. Adv Enzymol 33, 177-244.

Mansur, M., Suarez, T., Fernandez-Larrea, J., Brizuela, M. A. \& Gonzalez, A. E. (1997). Identification of a laccase gene family in the new lignin degrading basidiomycete CECT 20197. Appl Environ Microbiol 63, 2637-2646.

Martins, L. O., Soares, C., Pereira, M., Teixeira, M., Costa, T., Jones, G. H. \& Henriques, A. O. (2002). Molecular and biochemical characterization of a highly stable bacterial laccase that occurs as a structural component of the Bacillus subtilis endospore coat. J Biol Chem 277, 18849-18859.

Muñoz, C., Guillén, F., Martínez, A. T. \& Martínez, M. J. (1997). Laccase isozymes of Pleurotus eryngii: characterization, catalytic properties, and participation in activation of molecular oxygen and $\mathrm{Mn}^{2+}$ oxidation. Appl Environ Microbiol 63, 2166-2174.

O'Callaghan, J., O’Brien, M. M., McClean, K. \& Dobson, A. D. W. (2002). Optimization of the expression of a Trametes versicolor laccase gene in Pichia pastoris. J Ind Microbiol Biotechnol 29, $55-59$.

Otterbein, L., Record, E., Longhi, S., Asther, M. \& Moukha, S. (2000). Molecular cloning of the cDNA encoding laccase from Pycnoporus cinnabarinus I-937 and expression in Pichia pastoris. Eur J Biochem 267, 1619-1625.

Palmieri, G., Giardina, P., Bianco, C., Scaloni, A., Capasso, A. \& Sannia, G. (1997). A novel white laccase from Pleurotus ostreatus. J Biol Chem 272, 31301-31307.

Parkinson, N., Smith, I., Weaver, R. \& Edwards, J. P. (2001). A new form of arthropod phenoloxidase is abundant in venom of the parasitoid wasp Pimpla hypochondrica. Insect Biochem Mol Biol 31, 57-63. 
Potthast, A., Rosenau, T., Chen, C. L. \& Gratzl, J. S. (1996). A novel method for the conversion of benzyl alcohols to benzylaldehydes by laccase-catalysed oxidation. J Mol Catal Ser A 108, 5-9.

Record, E., Punt, P. J., Chamkha, M., Labat, M., van den Hondel, C. A. M. J. J. \& Asther, M. (2002). Expression of the Pycnoporus cinnabarinus laccase gene in Aspergillus niger and characterization of the recombinant enzyme. Eur J Biochem 269, 602-609.

Saloheimo, M. \& Niku-Paavola, M. L. (1991). Heterologous production of a ligninolytic enzyme: Expression of the Phlebia radiata laccase gene in Trichoderma reesei. Bio/Technology 9, 987-990.

Sanchez-Amat, A., Lucas-Elío, P., Fernández, E., García-Borrón, J. C. \& Solano, F. (2001). Molecular cloning and functional characterisation of a unique mutipotent polyphenol oxidase from Marinomonas mediterranea. Biochim Biophys Acta 1547, 104-116.

Sanger, F., Nicklen, S. \& Coulson, A. R. (1977). DNA Sequencing with chain-terminating inhibitors. Proc Natl Acad Sci US A 74, 5463-5467.

Schneider, P. \& Pedersen, A. H. (1995). PCT. World patent application WO 95/01426.

Shuttleworth, K. \& Bollag, J. M. (1986). Soluble and immobilized laccase as catalysts for the transformation of substituted phenols. Enz Microb Technol 8, 171-177.

Slomczynski, D., Nakas, J. P. \& Tanenbaum, S. W. (1995). Production and characterization of laccase from Botrytis cinerea 6134. Appl Environ Microbiol 61, 907-912.

Soden, D. M. (2002). Physiology and genetics of laccase production in Pleurotus sajor-caju. PhD thesis, National University of Ireland, Cork.

Soden, D. M. \& Dobson, A. D. W. (2001). Differential regulation of laccase gene expression in Pleurotus sajor-caju. Microbiology 147, 1755-1763.

Thomas, B. R., Yonekura, M., Morgan, T. D., Czapla, T. H., Hopkins, T. L. \& Kramer, K. J. (1989). A trypsin solubilised laccase from phrate pupal integument of the tobacco hornworm, Manduca sexta. Insect Biochem 19, 611-622.
Thurston, F. (1994). The structure and function of fungal laccases. Microbiology 140, 19-26.

Tomati, U., Galli, E., Di Lena, G. \& Buffone, R. (1991). Induction of laccase in Pleurotus ostreatus mycelium grown in olive oil waste warers. Agrochimica 35, 275-279.

Towbin, H., Staehelin, T. \& Gordon, J. (1979). Electrophoretic transfer of proteins from polyacrylamide gels to nitrocellulose sheets: procedure and some applications. Proc Natl Acad Sci US A 76, 4350-4354.

Toyama, N. \& Ogawa, K. (1974). Comparative studies on cellulolytic and oxidizing enzymes of edible and inedible wood rotters. Mushroom Sci 9, 745-760.

Von Heijne, G. (1986). A new method for predicting signal sequence clevage sites. Nucleic Acids Res 14, 4683-4690.

Wahleithner, J. A., Xu, F., Brown, K. M., Brown, S. H., Golightly, E. J., Halkier, T., Kauppinen, S., Pederson, A. \& Schneider, P. (1996). The identification and characterization of four laccases from the plant pathogenic fungus Rhizoctonia solan. Curr Genet 29, 395-403.

Wood, D. A. (1980). Production, purification and properties of extracellular laccase of Agaricus bisporus. J Gen Microbiol 117, 327-338.

Xu, F., Shin, W., Brown, S. H., Wahleiter, J. A., Sundaram, U. M. \& Salomon, E. I. (1996). A study of a series of recombinant fungal laccases and bilirubin oxidase that exhibit significant differences in redox potential, substrate specificity, and stability. Biochim Biophys Acta 1292, 303-311.

Yaver, D. S., Xu, F., Golightly, E. J. \& 7 other authors (1996). Purification, characterization, molecular cloning and expression of two laccase genes from the white rot basidimoycete Trametes villosa. Appl Environ Microbiol 62, 834-841.

Yaver, D. S., Del Carmen Overjero, M., Xu, F., Nelson, B. A., Brown, K. M., Halkier, T., Bernauer, S., Brown, S. H. \& Kaupinen, S. (1999). Molecular characterization of laccase genes from the basidiomycete Coprinus cinereus and heterologous expression of the laccase Lcc1. Appl Environ Microbiol 65, 4943-4948.

Received 22 April 2002; revised 26 August 2002; accepted 6 September 2002. 